University of Nebraska - Lincoln

DigitalCommons@University of Nebraska - Lincoln

\title{
Colony Connectivity of Pacific Coast Double-Crested Cormorants Based on Post-Breeding Dispersal From the Region's Largest Colony
}

\author{
Karen N. Courtot \\ Oregon State University, karen.courtot@gmail.com \\ Daniel D. Roby \\ Oregon State University, Daniel.Roby@orst.edu \\ Jessica Y. Adkins \\ Oregon State University, adkinsj@science.oregonstate.edu \\ Donald E. Lyons \\ Oregon State University, lyonsd@onid.orst.edu \\ D. Tommy King \\ USDA/APHIS/WS National Wildlife Research Center, tommy.king@aphis.usda.gov \\ See next page for additional authors
}

Follow this and additional works at: https://digitalcommons.unl.edu/icwdm_usdanwrc

Courtot, Karen N.; Roby, Daniel D.; Adkins, Jessica Y.; Lyons, Donald E.; King, D. Tommy; and Larsen, R. Scott, "Colony Connectivity of Pacific Coast Double-Crested Cormorants Based on Post-Breeding Dispersal From the Region's Largest Colony" (2012). USDA National Wildlife Research Center - Staff Publications. 1117.

https://digitalcommons.unl.edu/icwdm_usdanwrc/1117

This Article is brought to you for free and open access by the U.S. Department of Agriculture: Animal and Plant Health Inspection Service at DigitalCommons@University of Nebraska - Lincoln. It has been accepted for inclusion in USDA National Wildlife Research Center - Staff Publications by an authorized administrator of DigitalCommons@University of Nebraska - Lincoln. 


\section{Authors}

Karen N. Courtot, Daniel D. Roby, Jessica Y. Adkins, Donald E. Lyons, D. Tommy King, and R. Scott Larsen 


\title{
Colony Connectivity of Pacific Coast Double-Crested Cormorants Based on Post-Breeding Dispersal From the Region's Largest Colony
}

\author{
KAREN N. COURTOT, ${ }^{\mathbf{1 , 2}}$ Oregon Cooperative Fish and Wildlife Research Unit, Oregon State University, 104 Nash Hall, Corvallis, OR 97331, \\ $U S A$ \\ DANIEL D. ROBY, U.S. Geological Survey-Oregon Cooperative Fish and Wildife Research Unit, Oregon State University, 104 Nash Hall, \\ Corvallis, OR 97331, USA \\ JESSICA Y. ADKINS, Oregon Cooperative Fish and Wildlife Research Unit, Oregon State University, 104 Nash Hall, Corvallis, OR 97331 , USA \\ DONALD E. LYONS, Oregon Cooperative Fish and Wildife Research Unit, Oregon State University, 104 Nash Hall, Corvallis, OR 97331, USA \\ D. TOMMY KING, U.S. Department of Agriculture, National Wildlife Research Center, P.O. Box 6099, Mississippi State, MS 39762, USA \\ R. SCOTT LARSEN, ${ }^{3}$ Wildife Health Center, School of Veterinary Medicine, University of California, TB 128 Old Davis Drive, Davis, \\ CA 95616, USA
}

\begin{abstract}
To reduce conflicts with fish resources, other colonial waterbirds, and damage to habitats, double-crested cormorants (Phalacrocorax auritus) are currently controlled (lethally and non-lethally) throughout much of their range. Concerns are growing over the Pacific Coast's largest double-crested cormorant colony at East Sand Island (ESI), Oregon near the mouth of the Columbia River, where cormorants forage on juvenile salmonids, many of which are listed under the United States Endangered Species Act. Management of this colony is currently under consideration and may call for a redistribution of a portion of this colony numbering more than 12,000 breeding pairs in 2009 . We investigated regional and site-specific connectivity of ESI cormorants using satellite-telemetry to track post-breeding dispersal. Cormorants dispersed widely west of the Cascade-Sierra Nevada Mountains from British Columbia, Canada to northern Mexico. Tracking data demonstrated direct connectivity between the double-crested cormorant colony at ESI and nesting sites throughout the dispersal area. Results of this study indicate that some cormorants from ESI could disperse to prospect for nesting sites throughout much of the western portion of the range of the Western Population; however, regional variation in connectivity with the ESI population, distance from ESI, and site-specific nesting history will likely result in variable prospecting rates among regions and sub-regions. Management efforts aimed at redistributing ESI cormorants across western North America (e.g., social attraction or dissuasion techniques) might be best allocated to areas or sites known to be used by tagged cormorants, particularly those sites with an established nesting history. (C) 2012 The Wildlife Society.
\end{abstract}

KEY WORDS breeding dispersal, cormorant, Phalacrocorax auritus, prospecting, redistribution, satellite-telemetry.

Over the last 3 decades, populations of double-crested cormorants (Phalacrocorax auritus) recovering from historical lows have increasingly been perceived to be in conflict with other natural resource objectives (Duffy 1995, Hatch and Weseloh 1999, U.S. Fish and Wildlife Service [USFWS] 2003). Populations sharply reduced by unregulated take and the negative reproductive effects of

Received: 14 June 2011; Accepted: 2 March 2012;

Published: 22 June 2012

\footnotetext{
${ }^{1}$ E-mail: karen.courtot@gmail.com

${ }^{2}$ Present address: U.S. Geological Survey, Pacific Island Ecosystems Research Center, Kilauea Field Station, Hawaii National Park, HI 96718, USA.

${ }^{3}$ Present address: Denver Zoo, Denver, CO 80205, USA.
}

dichlorodiphenyltrichloroethane (DDT) have increased since the 1970s when they were afforded protection under the Migratory Bird Treaty Act in the United States and the use of DDT was restricted across North America (Hatch 1995). Although still below historical range-wide population levels, double-crested cormorants are currently abundant in many areas (Wires and Cuthbert 2006). Across North America, cormorants have been the subject of a range of management actions intended to reduce their impact on fish resources or vegetation, or to avoid local extirpation of other colonial waterbird species (USFWS 2003). To this end, depredation orders have been issued in the United States to allow for the take of cormorants without a federal permit in 24 states east of the Continental Divide (USFWS 1998, 2003). In Canada, cormorants are managed at the provincial level and in eastern and central provinces organized culls and 
other permitted take of cormorants occurs (Keith 1995). West of the Continental Divide (Alaska and Pacific Coast breeding zones), however, take of cormorants still requires a federal depredation permit in the United States and in Canada the species is protected by the British Columbia Wildlife Act (Moul and Gebauer 2002, USFWS 2003).

Genetic and leg-band recovery studies indicate that although populations are not entirely isolated, relatively little inter-mixing occurs among populations on either side of the Continental Divide (Dolbeer 1991, Mercer 2008, King et al. 2010). The cormorant population along the Pacific coast from southern British Columbia to northwestern Mexico, and from the coast eastward to the Continental Divide (the Pacific Coast breeding zone of Hatch and Weseloh 1999; hereafter referred to as the Western Population), has increased in recent years; however, not as rapidly as eastern populations (Adkins and Roby 2010). Growth of the Western Population since the late 1990s has been uneven and, rather than occurring throughout the range, has been largely the result of growth at 1 site, East Sand Island (ESI), Oregon, in the Columbia River estuary (Adkins and Roby 2010). The number of breeding pairs at ESI grew from fewer than 100 pairs in 1989 to more than 2,000 pairs in 1991 as a result of immigration from other colonies (Carter et al. 1995, Anderson et al. 2004a). In 2009, an estimated 12,087 pairs nested at ESI, approximately $40 \%$ of all double-crested cormorant-breeding pairs in the Western Population (Adkins and Roby 2010, Bird Research Northwest [BRNW] 2010).

The rapid expansion of the cormorant colony at ESI has drawn concern from fisheries managers over the potential impact of predation by these piscivorous birds on the survival of Columbia River basin juvenile salmonids (Oncorbynchus spp.) listed under the United States Endangered Species Act (ESA). Currently, Caspian terns (Hydroprogne caspia) are being managed in the Columbia River estuary to reduce their impact on the survival of ESA-listed salmonid smolts (USFWS 2006). In recent years, however, estimated salmonid smolt consumption by cormorants nesting on ESI has equaled or surpassed that of Caspian terns (Lyons 2010). As a result, management of the ESI double-crested cormorant colony is currently under consideration (National Oceanic and Atmospheric Administration 2008, 2010).

Similar to actions employed to manage Caspian terns in the Columbia River estuary (USFWS 2006), a management plan to reduce salmonid smolt losses to double-crested cormorants could include dispersal of a portion of the ESI nesting population by decreasing available nesting habitat or employing harassment techniques. Little is known, however, about the inter-colony movements and dispersal of cormorants from ESI, making it difficult for managers to assess which areas within the range of the Western Population may be most affected by any redistribution of nesting cormorants from this site.

To address the need for detailed information on prospective emigration of adult double-crested cormorants already breeding at ESI in response to potential management actions, we conducted the first satellite tracking study of double-crested cormorants west of the Continental Divide. The objectives of this study were to: 1 ) better understand the range and wintering distribution of doublecrested cormorants breeding at ESI in the context of the Western Population; 2) better understand connectivity of ESI cormorants with current and historical nesting sites; and 3) identify regions and locations where cormorants from ESI would likely prospect for alternative nest sites should redistribution of cormorants nesting at ESI be implemented as a management technique to reduce cormorant consumption of salmonids in the Columbia River estuary.

\section{STUDY AREA}

We studied the post-breeding season dispersal of doublecrested cormorants from ESI, Oregon, USA, in the Columbia River estuary $\left(46.26^{\circ} \mathrm{N}, 123.97^{\circ} \mathrm{W}\right.$; Fig. 1). Although greatly modified by anthropogenic activities including dredged material disposal and rip-rap stabilization, ESI is a naturally formed island that lies 8 river $\mathrm{km}$ inland from the Pacific Ocean (U.S. Army Corps of Engineers 2000). Double-crested cormorants nest at the western end of ESI almost exclusively on the ground in areas of accumulated flotsam and jetsam, on areas they clear of dune grass, or amongst rip-rap boulders. We collected post-breeding season roosting locations of cormorants throughout their dispersal range, regardless of distance from the nesting site, using satellite-telemetry. Cormorants used roost sites in a variety of marine and freshwater habitats including inland lakes and rivers, estuaries, protected coastal areas, and offshore rocky islets.

\section{METHODS}

\section{Cormorant Tracking}

During June and July of both 2008 and 2009, we captured breeding double-crested cormorants by hand from nests at ESI. We determined sex from blood samples collected from the tarsal vein. We tagged cormorants with 1 of 5 satellite tag (Platform Terminal Transmitter, PTT) and attachment configurations. We deployed battery-powered (Kiwisat 202 [50 g]; Sirtrack Limited, Havelock North, New Zealand]) and solar-powered PTTs (GS55 [50 g] and GS25 [39 g]High Water Pressure model; North Star Science and Technology, LLC, King George, VA) using a harness made of Teflon ribbon (described by Dunstan 1972, modified by King et al. 2000). We surgically implanted coelomic implant PTTs with external antennas (Kiwisat implant [33 g and $46 \mathrm{~g}$ ]; Sirtrack Limited; Hupp et al. 2006). Including all attachment materials, PTTs weighed $35-61 \mathrm{~g},<3.2 \%$ of bird's body mass in all cases. All animal handling protocols were approved by the Oregon State University Institutional Animal Care and Use Committee (Protocol no. 3722).

Battery- and solar-powered PTTs were programmed to use a 7-8:136-137 hour on:off and a 12:36 hour on:off dutycycle, respectively, to conserve battery power. On periods were programmed to coincide with the diurnal period cormorants were most likely to be at overnight roosting locations (2000-0800 Pacific Standard Time), rather than 


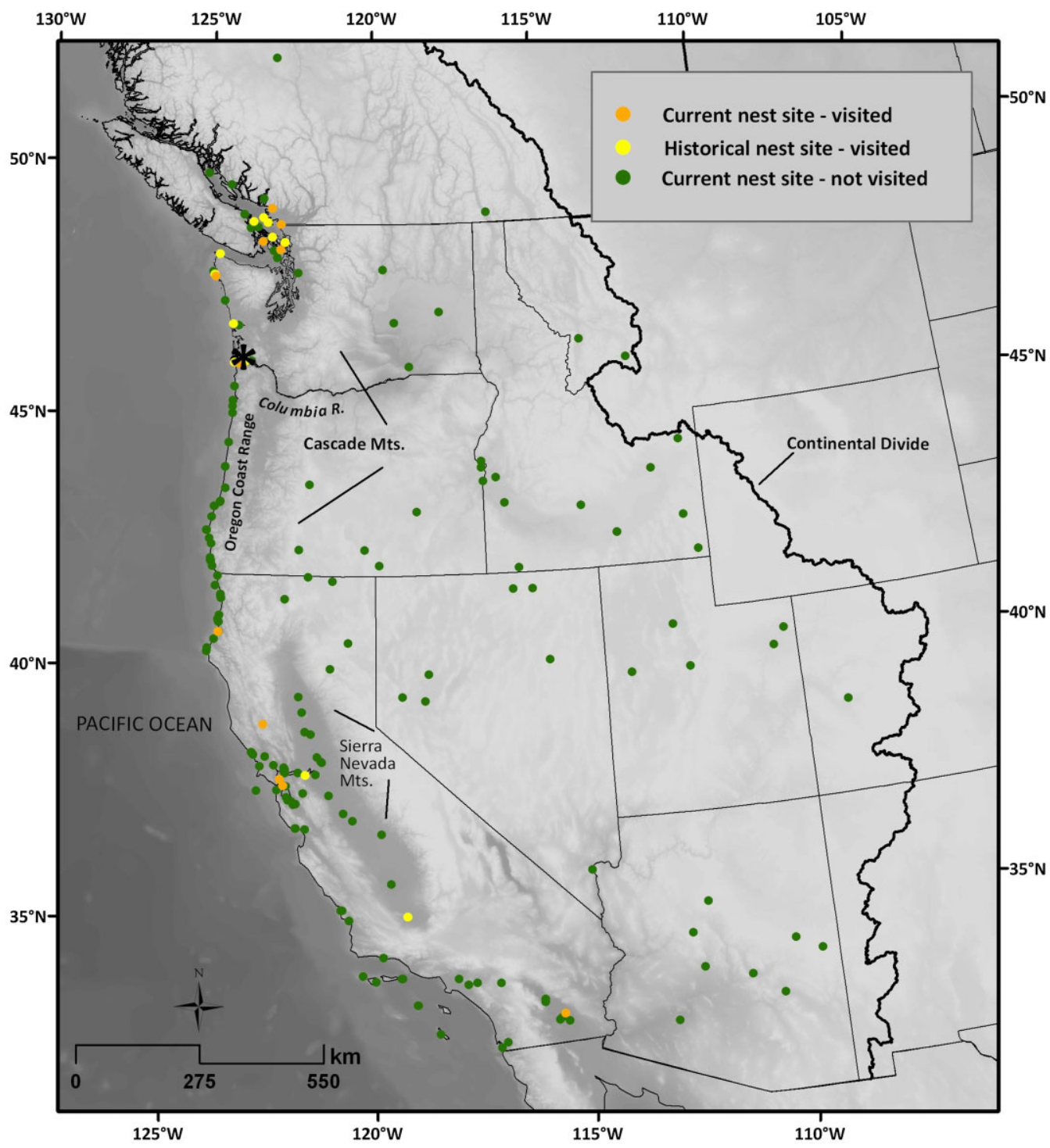

Figure 1. Distribution of current and historical double-crested cormorant nest sites across the range of the Western Population (excluding Mexico) visited by cormorants satellite-tagged while nesting (Jun-Jul) at East Sand Island, Oregon $(*) 2008$ and 2009. Only historical sites that were visited are shown. Adapted from Adkins and Roby (2010).

when cormorants would be foraging or actively moving among locations. We collected location data from 52 cormorants. Tracking period varied among individuals and years (Table 1). We observed some early transmitter failure caused by cormorants damaging or removing the antenna.

We received position fixes via the Argos satellite system (CLS America, Inc., Largo, MD). Argos assigned each position fix to 1 of 7 location classes (LC; 3, 2, 1, 0, A, $\mathrm{B}$, and $\mathrm{Z}$ ) on the basis of its accuracy. We filtered location data using the Douglas Argos-Filter Algorithm version 7.03
(USGS, Alaska Science Center, http://alaska.usgs.gov/ science/biology/spatial/douglas.html, accessed $12 \mathrm{Apr}$ 2010) programmed in SAS version 9.2 (SAS Institute, Cary, NC). We retained all LC 3 positions and all positions within $2 \mathrm{~km}$ of the subsequent location. We discarded consecutive positions requiring flying speeds $>70 \mathrm{~km} / \mathrm{hour}$. From this dataset, we selected 1 location per on period on the basis of best LC to identify a roost location. In cases of LC ties, we selected the best location based on the most messages received during the satellite overpass. We obtained

Table 1. Summary of double-crested cormorants satellite-tagged at East Sand Island, Oregon during June and July 2008 and 2009 including median (range) track end date per bird.

\begin{tabular}{lcccc}
\hline Deployment year & Male & Female & Total & Median (range) track end date \\
\hline 2008 & 10 & 6 & 16 & 2 Dec 2008 (2 Aug 2008-1 Jun 2009) \\
2009 & 21 & $15^{\mathrm{a}}$ & $36^{\mathrm{a}}$ & 23 Jan 2010 (13 Sep 2009-1 Jun 2010) \\
Total & 31 & 21 & $52^{\mathrm{a}}$ & 30 Dec (2 Aug 2008-1 Jun 2010) \\
\hline
\end{tabular}

${ }^{a}$ Includes 1 bird that remained resident in the Columbia River estuary region. 
all roosting locations from position fixes that had been rated by the Argos satellite system with a location error of $<1,500$ m (LC 3, 2, or 1; Argos 2007).

\section{Spatial Classification of Cormorant Location Data}

Where possible, we described cormorant roosting locations within regional and sub-regional areas as delineated in Carter et al. (1995) and Adkins and Roby (2010), which include comprehensive reviews of double-crested cormorant nesting west of the Continental Divide. These definitions allow evaluations of colony connectivity with regions and sub-regions where breeding population trends are documented. Additionally, we often used state and provincial political boundaries to delineate regions and sub-regions as these units were expected to be most meaningful to regional resource managers. To evaluate relative connectivity of ESI cormorants with regions, sub-regions, and nesting sites throughout the range of the Western Population, we determined the number of birds that used delineated areas.

To delineate the Columbia River estuary region (CRER), we centered a boundary circle on ESI with a radius of $40 \mathrm{~km}$, a distance near the upper limit of the foraging range of breeding cormorants at this site (Anderson et al. 2004b). We categorized all locations within the circle as within the CRER. We defined the departure date from the CRER as the median date between the last location within the CRER and the first location outside of the CRER.

We plotted location data for all known current and historical nesting sites documented in Adkins and Roby (2010). We categorized a nesting site as current in cases where nesting was confirmed during the 2008 or 2009 breeding seasons. We centered a circle at each nesting site with a radius equal to $2 \mathrm{~km}$ (to account for variability in the precision of colony site location and position fix error); we categorized roosting locations within the circle as at the nesting site. We did not weight use of delineated areas and nesting sites by length of stay or number of visits by a bird (i.e., connectivity with sites used for 1 night equal to that of sites that were used for multiple nights).

\section{Spatial and Statistical Analyses}

We used ArcGIS version 9.1 (Environmental Systems Research Institute, Inc. Redlands, CA) to plot and analyze filtered cormorant locations and nest site data. To account for the Earth's curvature, we calculated distances traveled using great-circle distances. We combined data among years, sexes, and tag types for assessments of general patterns of dispersal and connectivity. Females did not disperse as far north as males, as noted below, but were also pooled for most interpretations of general dispersal and connectivity. Means are presented as $\pm \mathrm{SD}$ in the text. After assessing data for normality, we used 2-sample $t$-tests to make comparisons between northward and southward migrating birds. We used a Satterthwaite adjustment for unequal variance where appropriate. We conducted all tests using SAS version 9.2 and set the significance level at $P=0.05$.

\section{RESULTS}

\section{Range}

Post-breeding double-crested cormorants $(n=52)$ dispersed up to $1,805 \mathrm{~km}$ from ESI to use roost sites near the northern and southern extremes of the nesting range of the Western Population (Figs. 1-3). Cormorants traveled to roosting locations as far north as the mouth of the Powell River in the northern Strait of Georgia, British Columbia, Canada $\left(49.9^{\circ} \mathrm{N}, 124.6^{\circ} \mathrm{W}\right)$ and as far south as the mouth of the Colorado River, Baja California, Mexico $\left(31.7^{\circ} \mathrm{N}\right.$, 114. $6^{\circ} \mathrm{W}$; Figs. 1-3). Cormorants did not make extensive movements into the eastern portion of the range of the Western Population with only 2 birds recorded east of the Cascade-Sierra Nevada Mountain range, 1 along the Columbia River (Interior Columbia Basin) and 1 bird in an interior state (Nevada; Figs. 2 and 3, Table 2).

\section{Columbia River Estuary Region-Use and Dispersal}

Double-crested cormorants from ESI used locations throughout the CRER as overnight roosts, including 5 of the 6 current and historical nesting sites in the region (Fig. 1). Cormorants dispersed from the CRER 1 July to 5 December (mean $=27$ Aug \pm 27.6 days, $n=51$; Fig. 4 ). One bird did not disperse from the CRER, but moved locally within the Columbia River estuary and nearby tributaries after all other tracked cormorants had dispersed. In general, cormorants ultimately dispersed in either a northward $(n=27 ; 18$ male, 9 female) or southward $(n=24$; 13 male, 11 female) direction from the CRER and did not travel to roost sites in both directions. Two estuaries $45 \mathrm{~km}$ and $75 \mathrm{~km}$ north of ESI, Willapa Bay and Grays Harbor, respectively, were commonly used by birds that later dispersed farther north and also those that ultimately traveled south of the CRER. Mean dispersal date differed $\left(t_{49}=2.59, P=0.01\right)$ between northward (mean $=18$ Aug \pm 21.4 days) or southward (mean $=7$ Sep \pm 30.7 days) migrating cormorants such that birds that used roosting areas to the south dispersed from the CRER an average of 18 days later than those that dispersed to the north (Fig. 4). Despite later departure from the CRER, the mean maximum dispersal distance was significantly greater for southward migrating birds (mean = $533.3 \pm 499.2 \mathrm{~km}$ ) compared to northward migrants (mean $=214.9 \pm 103.4 \mathrm{~km}$; Satterthwaite adjusted $t=$ 3.07, $P=0.005)$. We observed no significant correlation between maximum dispersal distance and tracking duration (adjusted for deployment date; $r^{2}<0.01$ ).

\section{Regional Connectivity}

Outside the CRER, double-crested cormorants dispersing from ESI demonstrated the greatest connectivity with estuarine and inner coastal regions to the north. Of any subregion, Willapa Bay was used by the greatest proportion of cormorants (61\%) and Grays Harbor was used by $35 \%$ of cormorants (Table 2). Farther north, 43\% of cormorants visited the sub-regions that cumulatively make up the Salish Sea, an inner coastal area that encompasses coastline and islands from the north end of the Strait of Georgia, 


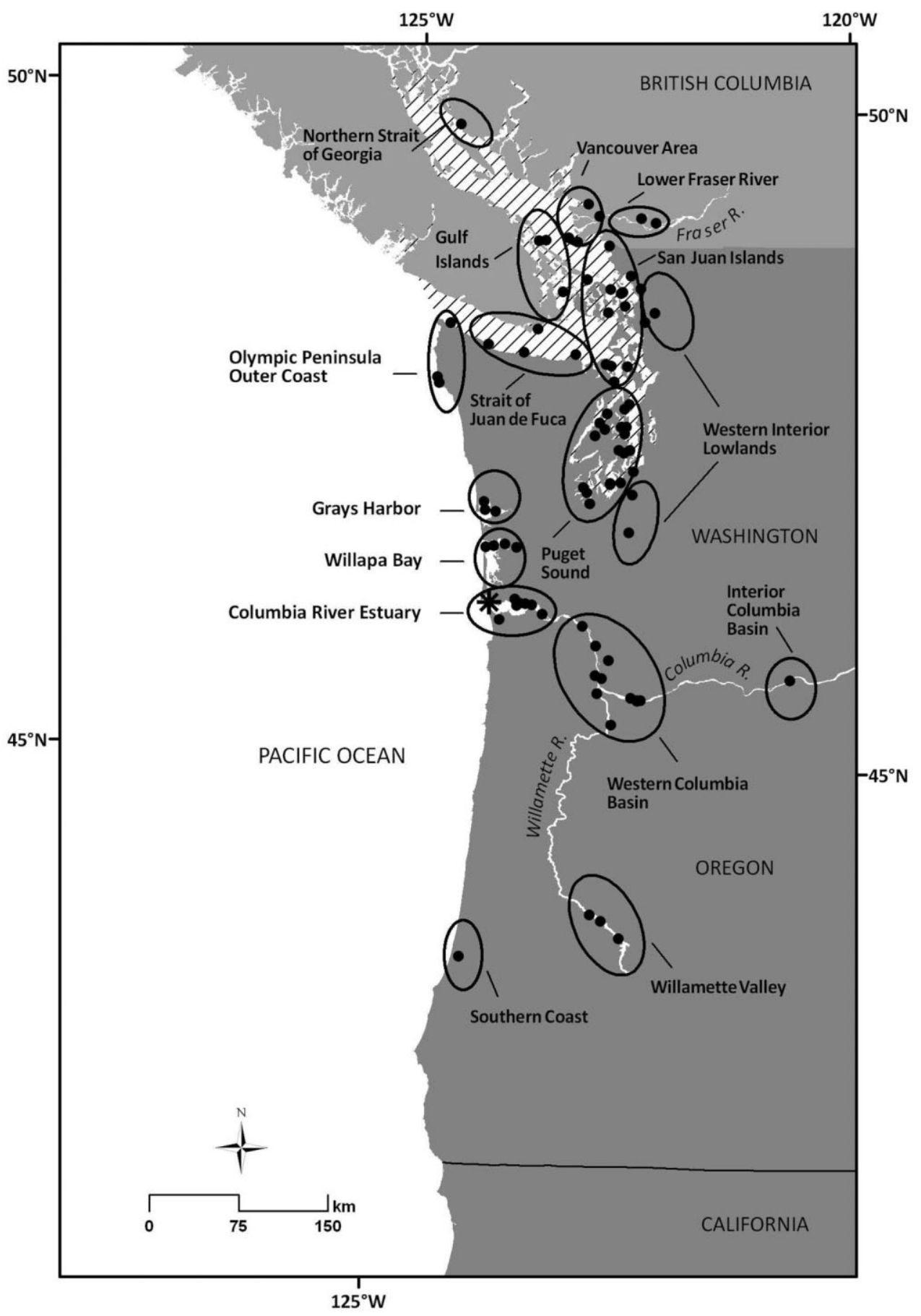

Figure 2. Post-breeding roosting locations $(\bullet)$ in Oregon, Washington, and British Columbia of double-crested cormorants satellite-tagged while nesting (JunJul) at East Sand Island, Oregon (*) 2008 and 2009. Salish Sea region represented with hatched background.

British Columbia to the west end of the Strait of Juan de Fuca to the south end of Puget Sound, Washington (Fig. 2, Table 2). Within the Salish Sea, the greatest proportion of cormorants used the Puget Sound (24\%) and the San Juan Island (18\%) sub-regions (Fig. 2, Table 2). The Strait of Georgia was used by a single cormorant. Although sexes overlapped through much of the dispersal range, no female cormorants used roost sites north of Seattle, Washington $\left(47.63^{\circ} \mathrm{N}\right)$ in the Puget Sound sub-region.

We observed limited connectivity with outer coastal regions from British Columbia to southern California.
Only 4\% of birds used rocky offshore islets, all within Washington's Olympic Peninsula (Fig. 2, Table 2). Only 1 coastal site along the southern Oregon coast, Tenmile Lake, was used by a single cormorant (2\%; Fig. 2, Table 2). Along the northern California coast, Arcata Bay (in the Northern Coast sub-region) was used by $6 \%$ of cormorants (Table 2). Ten percent of cormorants used roost sites in California's central coast, all within San Francisco Bay, the southernmost coastal area used.

Of any interior region, the Western Columbia Basin was used by the greatest proportion of cormorants, $20 \%$ 


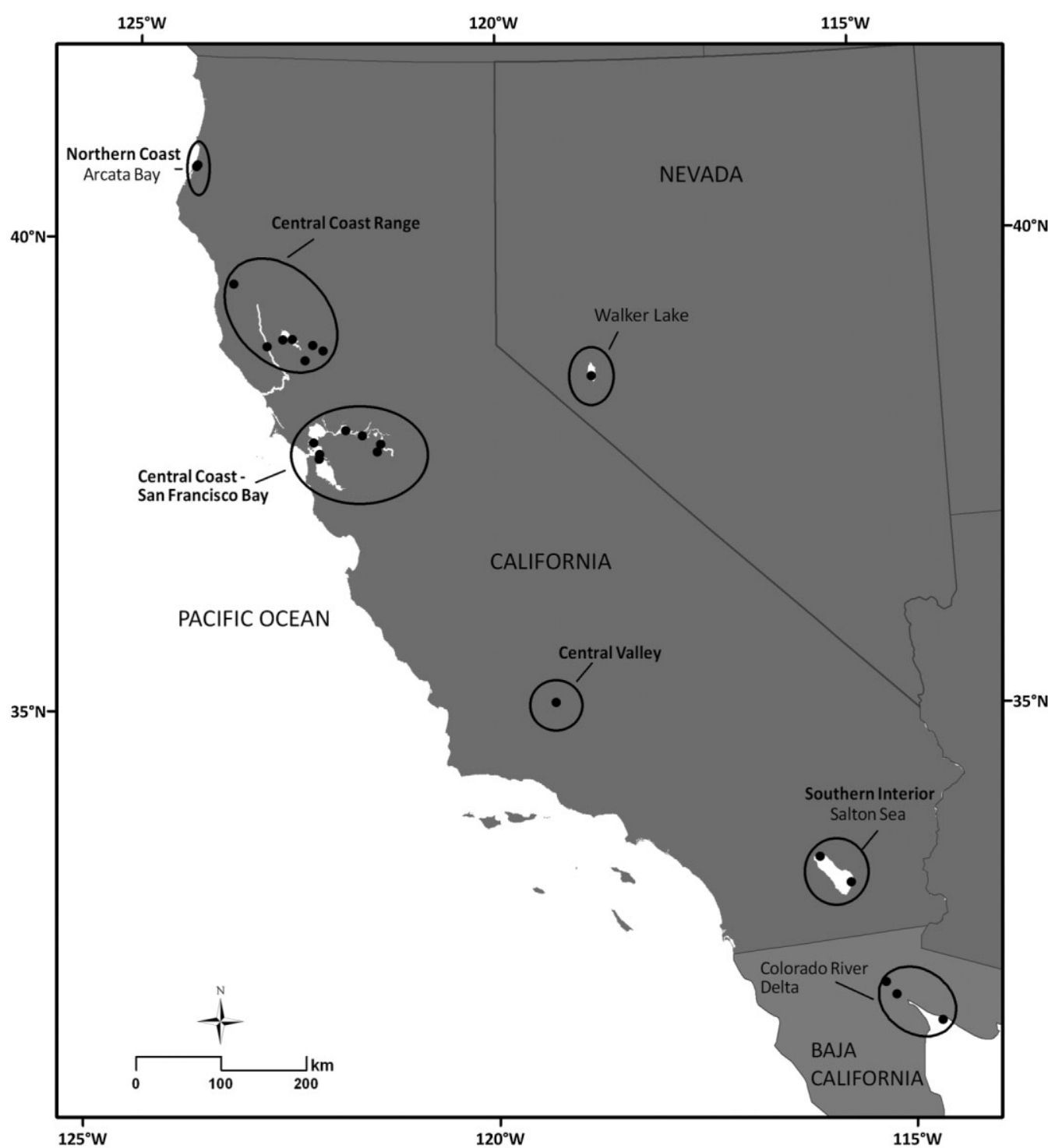

Figure 3. Post-breeding roosting locations (•) in California, Nevada, and Baja California of double-crested cormorants satellite-tagged while nesting (Jun-Jul) at East Sand Island, Oregon 2008 and 2009.

(Table 2). Cormorants in this region primarily used roost sites on islands within the Columbia and Willamette Rivers near the metropolitan areas of Portland, Oregon and Vancouver, Washington situated between the Oregon Coast Range and the Cascade Mountains (Fig. 2). However, we only tracked 1 cormorant (2\%) farther east along the Columbia River into the Interior Columbia Basin, east of the Cascade Mountains, to a roost site near the John Day Dam (Fig. 2, Table 2). Along the western edge of the Cascade Mountains, north of the CRER, 1 cormorant (2\%) roosted at sites along the lower Fraser River, British Columbia and $8 \%$ of cormorants roosted near lakes in Washington's Western Interior Lowlands (Fig. 2, Table 2). Farther south, $6 \%$ of birds used roost sites along rivers and reservoirs in the western foothills of the Cascade Mountains in the Willamette Valley (Fig. 2, Table 2). Within interior California, roost sites near lakes and rivers were used in the Central Coast Range (8\%) and Central
Valley sub-regions (2\%; Fig. 3, Table 2). Two cormorants (6\%) traveled to the Southern Interior sub-region of California and used roost sites at the Salton Sea. One of these individuals also used a roost site at a different lake in the same sub-region before crossing the Mexico border into Baja California and roosting along the Colorado River (Figs. 3 and 4, Table 2). The only site visited in an interior state, Walker Lake, Nevada, was used by 1 cormorant (2\%) on its return migration to ESI from the Salton Sea (Fig. 3).

\section{Colony Connectivity}

Three-quarters (38/51) of cormorants that dispersed from the CRER visited at least 1 of 9 current and 11 historical nesting sites outside of the CRER (Fig. 1, Table 3). Nesting sites used by post-breeding cormorants were located in coastal (inner and outer) and interior regions and varied in their habitat-type (e.g., rocky islets, sand islands, bridges, jetties). One-third (17/51) of cormorants roosted 
Table 2. Percentage of double-crested cormorants that used regions and sub-regions (indented) west of the Continental Divide, after dispersing from the Columbia River estuary region $(n=51)$. Region and sub-region headings follow Carter et al. 1995 and Adkins and Roby 2010 or state and provincial political boundaries.

\begin{tabular}{|c|c|}
\hline Region & Percentage (count) \\
\hline Interior British Columbia & $2(1)$ \\
\hline Lower Fraser River & $2(1)$ \\
\hline Coastal British Columbia-all & $14(7)$ \\
\hline Northern Strait of Georgia ${ }^{a}$ & $2(1)$ \\
\hline Vancouver Area ${ }^{a}$ & $10(5)$ \\
\hline Gulf Islands ${ }^{\mathrm{a}}$ & $6(3)$ \\
\hline Coastal Washington-all & $88(45)$ \\
\hline Salish Sea ${ }^{\mathrm{b}}$ & $43(22)$ \\
\hline Strait of Juan de Fuca ${ }^{a}$ & $6(3)$ \\
\hline San Juan Islands ${ }^{\mathrm{a}}$ & 18(9) \\
\hline Puget Sound $^{\mathrm{a}}$ & $24(12)$ \\
\hline Olympic Peninsula Outer Coast & $4(2)$ \\
\hline Grays Harbor & $35(18)$ \\
\hline Willapa Bay & $61(31)$ \\
\hline Western Columbia Basin & $20(10)$ \\
\hline Interior Washington- other $^{\mathrm{c}}$ & $10(5)$ \\
\hline Eastern Columbia Basin & $2(1)$ \\
\hline Western Washington Interior Lowlands & $8(4)$ \\
\hline Interior Oregon—other ${ }^{c}$ & $6(3)$ \\
\hline Willamette Valley & $6(3)$ \\
\hline Coastal Oregon & 2(1) \\
\hline Southern Coast & $2(1)$ \\
\hline Coastal California & $14(7)$ \\
\hline Northern Coast-North Section & $6(3)$ \\
\hline Central Coast-San Francisco Bay & $10(5)$ \\
\hline Interior California & $12(6)$ \\
\hline Central Coast Range & $8(4)$ \\
\hline Central Valley & $2(1)$ \\
\hline Southern Interior & $4(2)$ \\
\hline Interior States & 2(1) \\
\hline Nevada & $2(1)$ \\
\hline Coastal Mexico-Baja California & 2(1) \\
\hline Colorado River Delta & $2(1)$ \\
\hline
\end{tabular}

${ }^{\text {a }}$ Sub-region included in regional Salish Sea count.

${ }^{\mathrm{b}}$ Salish Sea region overlaps portions of Coastal British Columbia and Coastal Washington regions; birds were included in counts in both appropriate regions.

${ }^{\mathrm{c}}$ Excludes locations that are included in Western Columbia Basin Region.

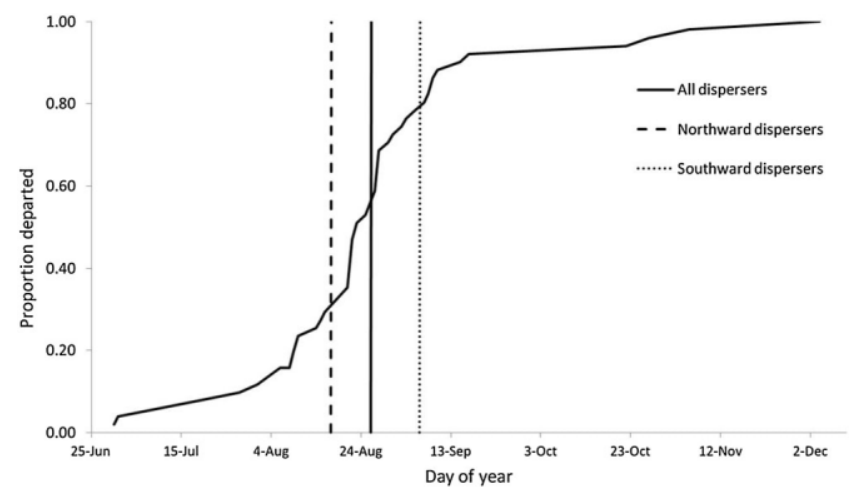

Figure 4. Cumulative proportion of double-crested cormorants satellitetagged while nesting (Jun-Jul) at East Sand Island, Oregon in 2008 and 2009 departing over time from the Columbia River estuary region $(n=51$, excludes 1 bird that was resident in the Columbia River estuary region for the entire tracking period). Mean departure dates are represented by vertical lines. at a historical nesting site in Grays Harbor, Washington and 19 cormorants used current and historical nesting sites elsewhere in the range. Three sub-regions most commonly used, Willapa Bay and Puget Sound, Washington, and the Western Columbia Basin, however, have no known nesting sites (Figs. 1-3, Tables 2 and 3). Among 11 cormorants tracked through spring migration, 10 visited historical or active nesting sites during the tracking period, but we observed no evidence of immigration as all returned to ESI.

North of Grays Harbor, in the Salish Sea, 10 cormorants used 1 or more of 4 current and 5 historical nesting sites (Figs. 1 and 2, Table 3). Along the outer Washington coast (Olympic Peninsula Outer Coast sub-region), 3 colonies ( 1 current and 2 historical) were each used by 1 of 2 cormorants dispersing to this sub-region (Figs. 1 and 2, Table 3). In these regions, all 5 current nesting sites and 6 of the 7 historical sites were visited before the end of September and some as early as June or July, when nesting would be underway or recently completed (Table 3 ).

Consistent with delayed southward dispersal, nesting sites south of the CRER were not used by ESI cormorants until September or later. On the northern California coast, a current breeding site in Arcata Bay was used by 2 cormorants and in San Francisco Bay, 3 colonies (2 current and 1 historical) were used by 1 of 3 cormorants (Table 3 ). In Interior California, Clear Lake (Lake County; classified as historical, but active breeding site when last surveyed in 1999) was used by 2 individuals (Table 3). In Southern Interior California, Mullet Island at the Salton Sea was visited by 2 birds (Table 3). Mullet Island is a somewhat unusual site where nesting activity has been documented in all months of the year, though no nesting occurs in some years. One cormorant arrived at Mullet Island in late October 2009 and remained there until March 2010, overlapping with ongoing breeding that was confirmed by a site visit (Adkins and Roby 2010).

Despite demonstrating connectivity with distant nesting sites and nest sites throughout much of the geographic range of the Western Population, we did not document connectivity with relatively nearby colonies along the Oregon coast or east of the Cascade-Sierra Nevada Mountain ranges (Fig. 1). Additionally, we did not document connectivity with nesting sites on the southern California coast or interior states (Fig. 1).

\section{DISCUSSION}

Our results provide the first evidence that adult doublecrested cormorants breeding at ESI disperse widely to locations near the northern and southern extremes of the Western Population range. Despite their broad dispersal within the range of the Western Population, our tracking results support leg band recovery data that suggest limited travel east of the Cascade-Sierra Nevada Range by cormorants reared in the Columbia River estuary (Clark et al. 2006) and genetic results that suggest limited intermixing with colonies in southwestern California (Mercer 2008). Additionally, our results provide further evidence that little interchange occurs between Pacific Coast colonies and 
Table 3. Current $(\mathrm{C})$ and historical $(\mathrm{H})$ nest sites outside of the Columbia River estuary region used by double-crested cormorants including region, sub-region, count of birds, and months the site was used. Region, sub-region, nest site names, and status follow Carter et al. (1995) and Adkins and Roby (2010).

\begin{tabular}{|c|c|c|c|c|c|}
\hline Region & Sub-region & Nest site & $\begin{array}{c}\text { Nesting } \\
\text { status }\end{array}$ & Count & $\begin{array}{c}\text { Months } \\
\text { used }\end{array}$ \\
\hline \multirow[t]{5}{*}{ Coastal British Columbia } & Vancouver Area $^{a}$ & Sand Heads & $\mathrm{H}$ & 1 & Sep-Apr \\
\hline & & $\begin{array}{l}\text { Second Narrows Bridge Power } \\
\text { Tower (NE Vancouver) }\end{array}$ & $\mathrm{C}$ & 1 & Jun and Nov \\
\hline & & Westshore Terminal & $\mathrm{H}$ & 2 & Sep-Dec \\
\hline & Gulf Islands ${ }^{\mathrm{a}}$ & Mandarte Island & $\mathrm{C}$ & 1 & Jul \\
\hline & & Canoe Islet & $\mathrm{H}$ & 1 & Dec \\
\hline \multirow[t]{8}{*}{ Coastal Washington } & San Juan Islands ${ }^{\mathrm{a}}$ & Drayton Harbor & $\mathrm{C}$ & 1 & Jul \\
\hline & & Bare Island & $\mathrm{H}$ & 1 & Sep \\
\hline & & Bird Rocks & $\mathrm{C}$ & 4 & Jul-Oct \\
\hline & & Viti Rocks & $\mathrm{H}$ & 5 & Jul-Oct \\
\hline & Olympic Peninsula Outer Coast & Seal Rock & $\mathrm{H}$ & 1 & Aug \\
\hline & & Petrel Island (Kohchaa) & $\mathrm{C}$ & 1 & Sep \\
\hline & & No Name 303 & $\mathrm{H}$ & 1 & Aug \\
\hline & Grays Harbor & Goose Island/Unnamed Sand Island & $\mathrm{H}$ & 17 & Jul-Oct \\
\hline \multirow[t]{4}{*}{ Coastal California } & Northern Coast-North Section & Arcata Bay Sand Islands & $\mathrm{C}$ & 2 & Oct \\
\hline & Central Coast-San Francisco Bay & Richmond-San Rafael Bridge & $\mathrm{C}$ & 1 & Jan \\
\hline & & San Francisco-Oakland Bay Bridge & $\mathrm{C}$ & 3 & Dec-Feb \\
\hline & & Donlon Island & $\mathrm{H}$ & 1 & Oct-Dec \\
\hline \multirow[t]{3}{*}{ Interior California } & Central Coast Range & Clear Lake (Lake Co.) & $\mathrm{H}$ & 1 & Nov-May \\
\hline & Southern Interior & Buena Vista Lake, Kern Co. & $\mathrm{H}$ & 1 & Nov \\
\hline & & Mullet Is., Salton Sea (So.) & $\mathrm{C}$ & 2 & Oct-Mar \\
\hline
\end{tabular}

${ }^{a}$ Sub-region in the Salish Sea region.

regions east of the Continental Divide (Dolbeer 1991, Mercer 2008, King et al. 2010), where some portions of the population in the United States are currently managed by depredation orders.

Results from this study were largely consistent with results from leg band recoveries of juvenile cormorants banded at ESI by Clark et al. (2006). Adult cormorants tagged in this study overlapped with the winter (Nov-Mar) distribution of juvenile cormorants banded at ESI (Clark et al. 2006) and demonstrated a clear pattern of connectivity with coastal regions to the north of the CRER and less connectivity with interior and coastal regions to the south. Variation in dispersal by first-time breeders (i.e., natal dispersal) and established breeders (i.e., breeding dispersal) is not, however, uncommon for double-crested cormorants (Dolbeer 1991, King et al. 2010) and other colonial bird species (Aebischer 1995, Serrano and Tella 2003, Henaux et al. 2007). Adults from this study were not recorded at non-coastal sites in southwestern California where, although few in number, juvenile cormorant bands were recovered, suggesting that dispersal of ESI cormorants into this area may largely be a result of natal rather than breeding dispersal.

Tracking data from this study suggest that after dispersing from the CRER or bays on the southern Washington coast, northward and southward migrating adults do not intermix during the post-breeding season. Although breeding and wintering ranges of Pacific Coast cormorants largely overlap and cormorants are year-round residents in some areas (Hatch and Weseloh 1999), cormorants breeding at ESI were almost exclusively migratory, confirming winter survey results of the Columbia River estuary that indicate few cormorants overwinter in the region (D. Roby, U.S. Geological Survey, unpublished data). Although double- crested cormorants generally exhibit fidelity to their colony site (Hatch and Weseloh 1999), they commonly immigrate to nearby colonies or re-colonize historical sites in response to disturbance (Carter et al. 1995, Stenzel et al. 1995, Wires and Cuthbert 2006, Duerr et al. 2009, Adkins and Roby 2010, King et al. 2010). If nesting habitat becomes limited at ESI because of management actions that make nest sites unavailable (e.g., elimination of nesting habitat) or undesirable (e.g., harassment), cormorants will likely prospect elsewhere within their range to find suitable alternative habitat (Duerr et al. 2009). Results of this study indicate that cormorants from ESI could disperse to prospect for nesting sites throughout much of the western portion of the range of the Western Population; however, regional variation in connectivity with the ESI population, distance from ESI, and site-specific nesting history will likely result in variable prospecting rates among regions and sub-regions.

If double-crested cormorants are unable to establish a nest site at ESI, we expect the proximity of alternative nesting sites will influence settlement decisions of prospecting cormorants as it does with other colonial species (Aebischer 1995, Serrano and Tella 2003, Henaux et al. 2007). Nearby $(<40 \mathrm{~km})$ current and historical nesting sites within the CRER that are regularly used as night (this study) and day roosts (D. Roby, unpublished data) during the breeding season are likely to have the greatest proportion of prospecting nesters. At nearby colonies such as these, birds are able to benefit from familiarity with foraging grounds and previously gathered information pertaining to local food availability (Henaux et al. 2007). Factors that may have limited nesting at other sites in the CRER in recent years, such as conspecific attraction and ample unoccupied habitat at ESI and adverse impacts of bald eagles (Haliaeetus leucocephalus) 
on small colonization attempts (D. Roby and Y. Suzuki, unpublished data), could be moderated if habitat is restricted and a large number of birds are precluded from nesting at ESI. A management plan to reduce system-wide consumption of salmonids will likely require dissuasion at these sites, as it has for Caspian terns.

Substantial connectivity with 2 nearby coastal Washington estuaries, Willapa Bay and Grays Harbor $(<80 \mathrm{~km}$ north; Fig. 2), suggests large numbers of prospecting cormorants unable to establish a nest site at ESI may visit these sites. The extremely low-lying sand islands in Willapa Bay, however, do not appear to provide suitable nesting habitat for doublecrested cormorants as they have not been recorded nesting in this region (Adkins and Roby 2010). In Grays Harbor, cormorants currently nest on channel markers (Adkins and Roby 2010) and tagged cormorants roosted at Goose Island as early as July, indicating breeding season foraging opportunities exist at this site. Although successful nesting at Goose Island has not occurred since 1999 (Adkins and Roby 2010), recent aerial surveys of the island indicate that suitable nesting habitat still exists at this site (D. Roby, unpublished data). However, large numbers of bald eagles have been observed in the vicinity of the island (D. Roby, unpublished data) and may be responsible, at least in part, for preventing re-colonization by cormorants. As with sites in the CRER, the effect of bald eagle disturbance at Goose Island could be minimized if large numbers of cormorants prospect concurrently.

Among more distant areas, adult ESI cormorants (this study) and juvenile cormorants (Clark et al. 2006) demonstrated a high degree of connectivity with the Salish Sea Region and to a lesser extent, the northern and central California coast sub-regions, areas in which numerous historical and current nesting sites exist (Adkins and Roby 2010; Fig. 1). Because settlement of dispersing colonial birds at breeding sites is often tightly linked to the presence of conspecifics (i.e., social attraction) and can be further linked to breeding conditions (i.e., productivity, density, etc.) at a settlement colony (Oro and Ruxton 2001, Henaux et al. 2007, Calabuig et al. 2010), the social information (e.g., presence of young of the year or nest structures) gathered by post-breeding birds about nesting sites in these regions may serve as cues for birds displaced from ESI to prospect in these regions. Indeed, cormorants generally arrived in the Salish Sea in the late summer or early fall when cormorant nesting would have been ongoing or recently completed. However, evidence of nesting can persist throughout the year at sites allowing social information to be gathered by later southward dispersers as well. Despite seasonal variation in food resources, cormorants displaced from ESI could also benefit from experience at foraging grounds in visited areas. We are unclear how the absence of post-breeding females in the northern portion of the Salish Sea in this study (i.e., where breeding colonies are located) may affect dispersal to more northern sites during the breeding season.

The lack of connectivity observed with both coastal Oregon and the Interior Columbia Basin during this study, in addition to the low rate of leg-band recoveries from these regions
(Clark et al. 2006) is surprising in light of the proximity to ESI of many breeding sites in these regions (Fig. 1). These regions, or other regions within the range of the Western Population not visited by cormorants in this study, may not experience a large number of prospecting birds from ESI, despite their proximity and the presence of breeding colonies. Conversely, we observed a high degree of connectivity with 3 areas in which no colony sites occur: Washington's Willapa Bay and Puget Sound and the Western Columbia Basin areas (Fig. 1; Adkins and Roby 2010). Despite the proximity of these regions to nesting areas and their frequent use during the non-breeding season, the lack of nesting history suggests these regions may not be suitable nesting areas.

\section{MANAGEMENT IMPLICATIONS}

Suitability of a location as a nesting site for double-crested cormorants and other colonial birds can be manipulated using habitat enhancement, predator control, protection from disturbance, and social attraction techniques to lure birds to specific nesting locations (e.g., Kress 1983, Roby et al. 2002, BRNW 2005). Conversely, techniques to deter cormorants from nesting in specific locations are also widely used as a management tool to influence nesting distributions (Sullivan et al. 2006, BRNW 2010). Results of this study indicate that if available nesting habitat at ESI were limited, some cormorants from this site could disperse to prospect for nesting sites throughout much of the western portion of the range of the Western Population. We expect, however, that regional variation in connectivity with the ESI population, distance from ESI, and site-specific nesting history will likely result in variable prospecting rates among regions and subregions. Management efforts aimed at redistributing ESI cormorants across western North America (e.g., social attraction or dissuasion techniques) might be best allocated to areas or sites known to be used by tagged cormorants, particularly those sites with an established nesting history.

\section{ACKNOWLEDGMENTS}

We thank J. Waldoch for assistance with in-field surgical implantations of transmitters. We also thank many field technicians for their valuable assistance, particularly $\mathrm{K}$. Atkins, L. Bayliss, S. Collar, L. Kerr, T. Marcella, S. Moculeski, K. Montgomery, M. Mudge, and A. PeckRichardson. Funding was provided by the U.S. Army Corps of Engineers, Portland District, Portland, Oregon (G. Dorsey and P. Schmidt) and the Bonneville Power Administration, Portland, Oregon (D. Welch). Permits were granted by the U.S. Fish and Wildlife Service (Region 1 Migratory Bird Office, Portland, OR) and the Oregon Department of Fish and Wildlife (Salem, OR). Mention of trademarks or commercial products does not imply endorsement by the U.S. Government. We thank 2 anonymous reviewers and C. Krause for insightful comments that improved an earlier draft of this manuscript. 


\section{LITERATURE CITED}

Adkins, J. Y., and D. D. Roby. 2010. A status assessment of the doublecrested cormorant (Phalacrocorax auritus) in western North America: 1998-2009. Final Report to the U.S. Army Corps of Engineers. U.S. Geological Survey, Corvallis, Oregon, USA.

Aebischer, N. J. 1995. Philopatry and colony fidelity of shags Phalacrocorax aristotelis on the east coast of Britain. Ibis 137:11-18.

Anderson, C. D., D. D. Roby, and K. Collis. 2004a. Conservation implications of the large colony of double-crested cormorants on East Sand Island, Columbia River Estuary, Oregon, USA. Waterbirds 27:155-160.

Anderson, C. D., D. D. Roby, and K. Collis. 2004b. Foraging patterns of male and female double-crested cormorants nesting in the Columbia River estuary. Canadian Journal of Zoology 82:541-554.

Argos. 2007. Argos user's manual. Collecte Localisation Satellites. Ramonville Saint-Agne, France. <http://www.argos-system.org/manual/>. Accessed 13 Jun 2011.

Bird Research Northwest [BRNW]. 2005. Piscivorous waterbird research on the Columbia River final 2004 season summary. Bird Research Northwest, Bend, Oregon, USA.

Bird Research Northwest [BRNW]. 2010. Piscivorous waterbird research on the Columbia River final 2009 season summary. Bird Research Northwest, Bend, Oregon, USA.

Calabuig, G., J. Ortego, J. M. Aparicio, and P. J. Cordero. 2010. Intercolony movements and prospecting behaviour in the colonial lesser kestrel. Animal Behaviour 79:811-817.

Carter, H. R., A. L. Sowls, M. S. Rodway, U. W. Wilson, R. W. Lowe, G. J. McChesney, F. Gress, and D. W. Anderson. 1995. Population size, trends, and conservation problems of the double-crested cormorant on the Pacific Coast of North America. Colonial Waterbirds 18:189-215.

Clark, A. C., T. M. Kollasch, and D. A. Williamson. 2006. Movements of double-crested cormorants fledged on the Columbia River estuary. Northwestern Naturalist 87:150-152.

Dolbeer, R. A. 1991. Migration patterns of double-crested cormorants east of the Rocky Mountains. Journal of Field Ornithology 62:83-93.

Duerr, A. E., T. M. Donovan, and D. E. Capen. 2009. Managementinduced reproductive failure and breeding dispersal in double-crested cormorants on Lake Champlain. Journal of Wildlife Management $71: 2565-2574$

Duffy, D. C. 1995. Why is the double-crested cormorant a problem? Insights from cormorant ecology and human sociology. Colonial Waterbirds 18:25-32.

Dunstan, T. C. 1972. A harness for radio-tagging raptorial birds. Inland Bird Banding News 44:4-8.

Hatch, J. J. 1995. Changing populations of double-crested cormorants. Colonial Waterbirds 18:8-24.

Hatch, J. J., and D. V. Weseloh. 1999. Double-crested cormorant (Phalacrocorax auritus). Account 441 in A. Poole and F. Gill, editors. The birds of North America. The Academy of Natural Sciences, Philadelphia, PA, and The American Ornithologists' Union, Washington, D.C., USA.

Henaux, V., T. Bregnballe, and J. D. Lebreton. 2007. Dispersal and recruitment during population growth in a colonial bird, the great cormorant Phalacrocorax carbo sinensis. Journal of Avian Biology 38:44-57.

Hupp, J. W., J. M. Pearce, D. M. Mulcahy, and D. A. Miller. 2006. Effects on abdominally implanted radiotransmitters with percutaneous antennas on migration, reproduction, and survival of Canada geese. Journal of Wildlife Management 70:812-822.

Keith, J. A. 1995. Management policies for cormorants in Canada. Colonial Waterbirds 18:234-237.

King, D. T., B. F. Blackwell, B. S. Dorr, and J. L. Belant. 2010. Effects of aquaculture on migration and movement patterns of double-crested cormorants. Human-Wildlife Conflicts 4:77-86.

King, D. T., M. E. Tobin, and M. Bur. 2000. Capture and telemetry techniques for double-crested cormorants (Phalocrocorax auritus). Pages
54-57 in Proceedings of the 19th Vertebrate Pest Conference, University of California, Davis, USA.

Kress, S. W. 1983. The use of decoys, sound recordings, and gull control for re-establishing a tern colony in Maine. Colonial Waterbirds 6: 185-196.

Lyons, D. E. 2010. Bioenergetics-based predator-prey relationships between piscivorous birds and juvenile salmonids in the Columbia River estuary. Dissertation, Oregon State University, Corvallis, USA.

Mercer, D. M. 2008. Phylogeography and population genetic structure of double-crested cormorants (Phalacrocorax auritus). Thesis, Oregon State University, Corvallis, USA.

Moul, I. E., and M. B. Gebauer. 2002. Status of the double-crested cormorant in British Columbia Wildlife Working Report Number WR-105. Ministry of Water, Land and Air Protection, Biodiversity Branch, Victoria, Canada.

National Oceanic and Atmospheric Administration. 2008. Federal Columbia River Power System 2008 Biological Opinion. National Marine Fisheries Service, Northwest Region, Seattle, Washington, USA.

National Oceanic and Atmospheric Administration. 2010. Supplemental consultation on remand for operation of the federal Columbia River power system, 11 Bureau of Reclamation Projects in the Columbia Basin and ESA Section 10(a)(I)(A) permit for juvenile fish transportation program (Revised and reissued pursuant to court order, NWF v. NMFS, Civ. No. CV 01-640-RE [D. Oregon]). National Marine Fisheries Service, Northwest Region, Seattle, Washington, USA.

Oro, D., and G. D. Ruxton. 2001. The formation and growth of seabird colonies: Audouin's gull as a case study. Journal of Animal Ecology 70:527-535

Roby, D. D., K. Collis, D. E. Lyons, D. P. Craig, J. Y. Adkins, A. M. Myers, and R. M. Suryan. 2002. Effects of colony relocation on diet and productivity of Caspian terns. Journal of Wildlife Management 66:662-673

Serrano, D., and J. L. Tella. 2003. Dispersal within a spatially structured population of lesser kestrels: the role of spatial isolation and conspecific attraction. Journal of Animal Ecology 72:400-410.

Stenzel, L. E., H. R. Carter, R. P. Henderson, S. D. Emslie, M. J. Rauzon, G. W. Page, and P. Y. O'Brien. 1995. Breeding success of double-crested cormorants in the San Francisco Bay area, California. Colonial Waterbirds 18:216-224.

Sullivan, K. L., P. D. Curtis, R. B. Chipman, and R. D. McCullough. 2006. The double-crested cormorant issues and management. Department of Natural Resources, Cornell University, Ithaca, New York, USA.

U.S. Army of Corps Engineers. 2000. Caspian tern relocation FY 2000 management plan and pile dike relocation, Clatsop County, Oregon and Grays Harbor County, Washington: environmental assessment and finding of no significant impact. U.S. Army Corps of Engineers, Portland, Oregon, USA.

U.S. Fish Wildlife Service [USFWS]. 1998. Establishment of a depredation order for the double-crested cormorant. Final Rule. Federal Register 63:10550-10561.

U.S. Fish Wildlife Service [USFWS]. 2003. Double-crested cormorant management in the United States Final Environmental Impact Statement. U.S. Fish and Wildlife Service, Division of Migratory Bird Management, Arlington, Virginia, USA

U.S. Fish Wildlife Service [USFWS]. 2006. Record of Decision: Caspian tern management to reduce predation of juvenile salmonids in the Columbia River estuary, Final Environmental Impact Statement. U.S. Fish and Wildlife Service, Migratory Birds and Habitat Programs, Portland, Oregon, USA.

Wires, L. R., and F. J. Cuthbert. 2006. Historic populations of the doublecrested cormorant (Phalacrocorax auritus): implications for conservation and management in the 21st century. Waterbirds 29:9-37.

Associate Editor: Michael Chamberlain. 